\title{
Conflict over Conflict: The Right to Strike in International Law
}

\author{
Diane F. Frey, San Francisco State University, United States of America
}

\begin{abstract}
The existence of a right to strike under international law has been challenged by the International Organization of Employers since the late 1980s. The employer group claims that no such right exists under international law and has been moving to undermine recognition of the right at the International Labour Organisation (ILO). This article examines the right to strike in international human rights law. It considers specifically the International Covenant on Economic, Social and Cultural Rights (ICESCR) and the International Covenant on Civil and Political Rights (ICCPR) and finds that the right to strike exists in both of these treaties. Further, the article demonstrates that while the ILO employers group may challenge the existence of the right to strike, its government members have overwhelmingly ratified international human rights treaties contradicting the employer group's position that there is no such right.
\end{abstract}

\section{KEYWORDS}

right to strike; ILO; freedom of association; human rights

Today, 64 years since the United Nations declared December 10 a Human Rights Day, the world is witnessing an unprecedented attack on one of the most fundamental human rights of all, the right to strike (International Trade Union Confederation Statement on Human Rights Day, 2014a).

\section{Introduction}

In recent years, there has been a conflict at the International Labour Organisation (ILO) over whether there is a right to strike under ILO Convention No. 87 (1948) on Freedom of Association and Protection of the Right to Organise. With respect to the ILO, the right to strike has received newfound interest and re-examination in recent years (Novitz, 2003; Bellace, 2014a; Hofmann, 2014). In a thorough recounting of ILO history concerning the right to strike, Janice Bellace (2014a) persuasively argues that the right to strike is indeed an inherent corollary to freedom of association under Convention No. 87. Bellace (2014a: 31) noted that during discussions leading up to adoption of Convention No. 87 at the ILO in 1948, there was no explicit discussion or debate about the inclusion of right to strike. She explains that its absence from discussions and the text of Convention No. 87 were due to the fact that the parties assumed that the right to strike was an integral and not separate element of freedom of association (Bellace, 2014a: 42). As Tonia Novitz (2003: 92) has remarked, "the ILO sees freedom of association and the right to strike as inseparably linked".

This article takes a different approach from Bellace and Novitz by examining the existence of

Global Labour Journal, 2017, 8(1), Page 17 
the right to strike outside of ILO Convention No 87. The article considers the right to strike under international human rights treaties, such as the International Covenant on Economic, Social and Cultural Rights (ICESCR) and the International Covenant on Civil and Political Rights (ICCPR). It argues that the right to strike is enshrined in international law and, further, that a vast majority of ILO member states are parties to these treaties and thereby, have recognised the right to strike. In this light, the recent controversy at the ILO over whether there is or should be a right to strike would be better framed in a holistic fashion taking into account broader human rights obligations of ILO member states. After this introduction, this article (1) briefly outlines the history of the controversy at the ILO, (2) explains the right to strike under the ICESCR and the ICCPR, (3) demonstrates widespread ILO member state support and ratification of treaties recognising the right to strike, and (4) concludes that, notwithstanding employer opposition to the inclusion of the right to strike under ILO Convention No. 87, the conflict at the ILO will be less intractable if government representatives at the ILO remain faithful to their existing commitments to international treaties recognising the right to strike.

\section{Background}

The ILO is unique for its tripartite structure. As with the United Nations (UN), countries are members of the ILO. Unlike the United Nations, however, each member state receives four votes: one vote for the employers, one vote for the worker representatives, and two votes for government representatives. Among the cornerstones of the ILO's work is legislating and monitoring international labour standards through this tripartite governance structure, such as its tripartite Committee on Freedom of Association (CFA) (ILO, Undated a).

The ILO has been in increasing turmoil since 1989 when the employer group, the International

Organisation of Employers (IOE), began systematically claiming there is no right to strike under ILO Conventions (La Hovary, 2013: 361). Although the specific arguments have evolved, the employer group's overall claim has been that there is no international right to strike. They base their position on the absence of an explicit provision enumerating the right to strike in Convention No. 87. The Convention provides workers with freedom to join organisations of their own choosing and bestows upon those organisations the right to organise their activities and programmes. It does not, however, explicitly name the right to strike in the text (ILO, Undated b; Convention No. 87: articles 2, 3, 8 and 10; Bellace, 2014a: 30). Further, the employer group argues that one of the ILO's supervisory bodies, the Committee of Experts, lacks authority to imply the right to strike in Convention No. 87 because "only the International Court of Justice can give authoritative interpretations of ILO Conventions" (IOE, 2013: 7).

Worker representatives have responded that the right to strike has rightfully been considered as part of ILO Conventions on Freedom of Association without interruption since 1948, including by employer members who have served on the tripartite Committee on Freedom of Association (ITUC, 2014b: 17). According to worker representatives, the attack on the right to strike is part of a larger effort to undermine the authority of the ILO to monitor and enforce labour standards and to turn hard labour standards law into soft law (Hofmann, 2014: 1; ITUC, 2014b: 8).

The origins of the employer group's opposition to recognition of the right to strike have been attributed to several related factors such as the end of the Cold War, the ascendency of employer power relative to labour, and the increasing influence of ILO non-binding pronouncements in 
domestic policy, as well as regional and domestic court decisions (La Hovary, 2013: 365). Indeed, ILO standards on the right to strike have influenced soft laws such as the OECD guidelines for Multinational Enterprises and the UN Guiding Principles for Business and Human Rights (Van de Heijden, 2013: 3; Bellace, 2014a: 59). ILO standards have also influenced court decisions including the recent Supreme Court decision in Canada reaffirming the right to strike (Saskatchewan

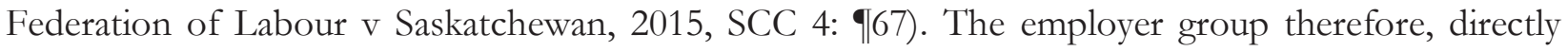
challenges the ILO's legitimacy and influence.

The disagreement at the ILO has not just been rhetorical. In 2012, the employer group refused to cooperate with the yearly Committee on Application of Standards (CAS) that receives reports from the Committee of Experts and arranges hearings at the ILO annual conference to draw attention to serious problems of labour standards enforcement among ILO member countries (Hofmann, 2014: 1; ITUC, 2014b: 5). Ironically, the employers' concerted activity amounted to a de facto strike that prevented ILO supervisory mechanisms from working as intended under its Constitution. A subsequent compromise was reached under which the employers agreed to cooperate with CAS proceedings and agenda items as long as they did not deal with the issues related to the right to strike (Hofmann, 2014: 2).

The conflict continued to escalate and in October 2013 the ITUC General Council passed a resolution to seek referral of the conflict to the International Court of Justice (ICJ) (ITUC, 2014b: 10). Although the employer group argued that the ICJ is the only competent authority that can render an opinion on the status of the right to strike under Convention No. 87, they did not seek referral to the court (IOE, 2013: 7; ITUC, 2015: 94). The ILO Governing Body took up discussion of the conflict in March and November of 2014, and decided to engage in further dialogue and exploration of options to resolve the conflict in late February 2015 (IOE, 2014: ף209). In addition to the possibility of referral to the ICJ, there was also to be consideration of an internal ILO procedure to resolve the dispute by establishing a tribunal under article 37.2 of the ILO Constitution. The employer group, with support of some government representatives, advocated for the extended dialogue and the tribunal as an alternative to the ICJ (ILO, 2014: 947-208). The ITUC noted in its follow-up report from the November 2014 meeting that countries which hardly embrace social dialogue at home with their own social partners were fervently eager to embrace it at the ILO, most likely in an attempt to delay an opinion from the ICJ (ITUC, 2015: \6).

A special meeting took place in February 2015 at the ILO in Geneva to pursue continued dialogue on the conflict over the existence of a right to strike as well as alternative ways that the ILO could address bolstering support for its labour standards supervisory system. In preparation for the meeting, ITUC affiliates organised an international day of protest on February 18 to support the right to strike. The Tripartite Meeting held on February 23-25 seems to have deferred the internal conflict at the ILO, at least for the moment (IndustriALL, 2015: 1). The employer and worker representatives issued a joint statement noting their recognition of the "right to take industrial action by workers and employers in support of their legitimate industrial interests" (ILO, 2015b: Appendix I). The statement does not, however, signal acceptance of the Committee of Experts jurisprudence on the right to strike as binding or authoritative. Governments at the meeting issued a statement recognising the right to strike as linked to freedom of association and a fundamental principle and right at work, but its scope and the conditions of the right are regulated at the national level (ILO, 2015b: Appendix II, \5).

Global Labour Journal, 2017, 8(1), Page 19 


\section{International Treaties on the Right to Strike}

International human rights treaties contradict the employer group's claim that there is no international right to strike. This is most evident in the International Covenant on Economic, Social and Cultural Rights, which is the international treaty with the most expansive list of work-related rights including a specific provision for the right to strike. In addition, although not explicitly included among the rights enumerated in the International Covenant on Civil and Political Rights, the Human Rights Committee (HRC), which is responsible for monitoring implementation of the treaty, has upheld the right to strike under its provisions since 1999 (Scheinin and Langford, 2009: 102; UN HRC, 1999: ๆ25).

\section{The International Covenant on Economic, Social and Cultural Rights}

The work rights enumerated in the ICESCR support many elements of the ILO Decent Work Agenda and ILO Conventions (MacNaughton and Frey, 2011: 444). The Covenant's work-related rights include the right to freely chosen work, the right to full employment, the right to fair wages, the right to an adequate standard of living, the right to safe and healthy working conditions, the right to rest and leisure, the right to form and join trade unions, the right of unions to function freely and the right to social security (ICESCR, 1976: art 6(1), 7(a)(i), 11(1), 7(b), 7(d) and 8(a)), 8(c), 8(d)). Notably, the ICESCR explicitly includes the right to strike among the union rights elaborated in article 8. The treaty states, "The State Parties to the present Covenant undertake to ensure: (d) The right to strike, provided that it is exercised in conformity with the laws of the particular country" (ICESCR, 1976: art 8(1)(d)). Article 8(2) specifies the limits that countries may place on the right, noting that "the article shall not prevent the imposition of lawful restrictions on the exercise of these rights by members of the armed forces or of the police or of the administration of the State" (ICESCR, 1976: Art 8(2)). Finally, Article 8(3) prevents state parties from using the Covenant to undercut or prejudice rights that are provided in ILO Convention No. 87. It states:

Nothing in this article shall authorize State Parties to the International Labour Organisation Convention of 1948 concerning Freedom of Association and Protection of the Right to Organise to take legislative measures which would prejudice, or apply the law in such a manner as would prejudice, the guarantees provided for in that Convention (ICESCR, 1976: 8(3)).

This latter provision was cited in upholding the right to strike, in Canada when the Canadian Court referenced this provision of the ICESCR in Saskatchewan Federation of Labour v Saskatchewan (2015 SCC 4: $₫ 68$ ).

Matthew Craven, a professor of international law, published an examination of the origins and development of the ICESCR, including of the right to strike. He shows that there was extensive debate among the country representatives drafting the Covenant about whether or not to include the right to strike in the Covenant (Craven, 1995: 257). Indeed, numerous arguments were put forward for omitting it. However, the majority of the drafting committee believed that "the right to strike was essential for the protection of the economic and social interests of workers" (Craven, 1995: 257 and fn 85). The drafters recognised that it was "meaningless to try to guarantee trade union rights without a right to strike" (Craven, 1995: 257 fn 86).

Debate among drafters also focused on what, if any, limitations should be placed upon worker rights to strike. The need to spell out circumstances in which strikes should be limited was 
questioned by the representative from Yugoslavia who noted that "given the financial constraints on strikes, unjustified strike action was extremely unlikely" (Craven, 1995: 258 fn 100). The Yugoslavian country representative also cautioned that, "for its own security considerations", it was dangerous and potentially open to abuse to allow the state alone to judge exemptions from the right (Craven, 1995: 258 fn 98). Further, the representative from the USSR argued that such limitations might "encourage governments to attack trade union rights" (Craven, 1995: 258 fn 99). Ultimately, the agreed language limiting the right to strike appeased those who opposed its inclusion by making the right "subject to the laws of the particular country", raising the concern that a particular country could render it "virtually inoperable" (Craven, 1995: 259). Nevertheless, national limits on the right to strike in the Covenant were to be narrowly applied to the armed forces, police and employees involved in the administration of the state (ICESCR, 1976: Art 8(2)). Further, state parties to the treaty were not to be allowed to use the national limits to undercut provisions of Convention No. 87 (ICESCR, 1976: Art 8(3)).

The fact that the right to strike has not been rendered "virtually inoperable" under the ICESCR is largely due to the work of the Committee on Economic, Social and Cultural Rights (CESCR) which monitors the ICESCR's implementation by countries that adopt the treaty. The UN Economic and Social Council (ECOSOC) established the CESCR in 1985 as the body responsible for the interpretation and supervision of the ICESCR (Saul, Kinley and Mowbray 2014: 4). The CESCR consists of eighteen members. Countries first report within two years of ratifying the ICESCR and thereafter every five years on their implementation of the treaty (OHCHR, Undated a). The CESCR has issued over 300 Concluding Observations on the state reports since 1992 (Saul et al., 2014: 5).

The CESCR has continued to interpret the meaning and obligations under the Covenant with respect to the right to strike. Saul et al. (2014: 579-586) trace the Committee's work interpreting the right to strike along lines that are independent yet cognizant of and congruent with opinions of the ILO Committee of Experts and Committee on Freedom of Association. Under the ICESCR, states must adopt a legal framework recognising the right to strike and protect the right from unlawful interference, and they must also provide effective machinery for the protection of the right and the determination of disputes over it (Saul et al., 2014: 580). Concluding Observations concerning Germany in 2001 illustrate the Committee's interpretation of the right to strike under the ICESCR relative to ILO Conventions and their interpretation:

The Committee reiterates its concern, in line with the Human Rights Committee and the ILO Committee of Experts, that the prohibition by the State party of strikes by public servants other than public officials who do not provide essential services, such as judges, so-called Beamte and teachers, constitutes a restriction of the activities of trade unions that is beyond the scope of article 8 (2) of the Covenant. The Committee disagrees with the State party's statement that 'a strike would be incompatible with this duty of loyalty and would run counter to the purpose of a professional civil service' (E/C.12/4/Add.3, para. 82), as this interpretation of 'the administration of the State' mentioned in article 8 (2) of the Covenant exceeds the more restrictive interpretations by the Committee, the ILO (Convention No. 98) and the European Court of Justice (CESCR, 2001a). ${ }^{1}$

\footnotetext{
${ }^{1}$ See also Judy Fudge (2015) for a discussion of the role of courts in Canada and Europe in interpreting the right to strike.
} 
In addition to Concluding Observations, the CESCR also issues General Comments, which are considered "authoritative statements" of its opinions. While they are not formally binding, they are considered "highly influential" in establishing the scope and meaning of rights in the ICESCR (Saul et al., 2014: 5). In 2006 the CESCR issued General Comment 18 on the right to work under article 6 of the ICESCR but did not elaborate on the collective dimension of the right to work addressed in article 8, which enunciates the right of everyone to form trade unions and join the trade union of their choice as well as the right of trade unions to function freely (CESCR, 2006: 2 T2). The Committee noted, however, that the work rights in articles 6, 7 and 8 of the ICESCR are interrelated and interdependent (CESCR, 2006: 3 98). While the Committee has issued General Comments on the work rights in article 6 (general right to freely choose work and full employment), article 7 (right to just and favourable conditions of work) and article 9 (right to social security), the Committee has not yet issued a General Comment on article 8 (union rights) or on the right to strike.

\section{The International Covenant on Civil and Political Rights}

There is no explicit provision on the right to strike in the ICCPR. Article 22 on freedom of association states, "Everyone shall have the right to freedom of association with others, including the right to form and join trade unions for the protection of his interests" (ICCPR, 1976: art 22(1)). It further provides that:

No restrictions may be placed on the exercise of this right other than those which are prescribed by law and which are necessary in a democratic society in the interests of national security or public safety, public order (ordre public), the protection of public health or morals or the protection of the rights and freedoms of others. This article shall not prevent the imposition of lawful restrictions on members of the armed forces and of the police in their exercise of this right (ICCPR, 1976: art 22(2)).

As with the ICESCR, the ICCPR makes special allowances for the ILO and Convention No. 87, stating in section 3:

Nothing in this article shall authorize State Parties to the International Labour Organisation Convention of 1948 concerning Freedom of Association and Protection of the Right to Organise to take legislative measures which would prejudice, or to apply the law in such a manner as to prejudice, the guarantees provided for in that Convention (ICCPR, 1976: art 22(3)).

There are 168 parties to the ICCPR, of which 163 are members of the ILO. Each party submits reports to the 18-member Human Rights Committee, initially one year after becoming a party to the treaty and every four years thereafter. After examining state reports, the HRC issues Concluding Observations outlining its concerns and recommendations. In addition, the HRC administers a complaints procedure under the treaty and issues General Comments elaborating on the content of the treaty. The HRC ruled in a 1986 case, J.B. v Canada, that the right to strike was not protected under the ICCPR (HRC, 1986; Macklem, 2005: 27). What must be highlighted, however, is that after this 1986 determination, the HRC has subsequently veered towards consistently upholding the right to strike. There has not been another complaint leading to a formal case in which the HRC has ruled on the right to strike, but since 1999 the HRC has made comments on periodic reports submitted by 
countries that are party to the treaty, affirming the existence of a right to strike under the ICCPR (Macklem, 2005: 72-73; HRC, 2004: ๆ18; HRC, 2010: ๆ15). For example, in 2010 in its concluding observations on Estonia, the HRC observed:

While noting that the present draft Public Service Act presented to Parliament includes a provision restricting the number of public servants not authorized to strike, the Committee is concerned that public servants who do not exercise public authority do not fully enjoy the right to strike (HRC, 2010: art. 22).

The State Party should ensure in its legislation that only the most limited number of public servants is denied the right to strike (HRC, 2010: 915$)$.

In sum, the ICCPR and the ICESCR recognise the right to strike and, that it entails obligations for countries that are parties to the treaties to respect, protect and fulfil the right to strike. Of course, these are obligations only of countries that have become state parties through the process of ratification or accession. As indicated in the following section, both the ICCPR and ICESCR enjoy widespread acceptance among countries that are members of the ILO, including countries that have ratified ILO Convention No. 87 on Freedom of Association that has been the subject of controversy.

\section{ILO Member State Support and Ratifications of Treaties Recognising the Right to Strike}

The treaties examined above on the right to strike have been widely adopted by ILO member states through the ratification process. There are 168 parties to the ICCPR, of which 163 are ILO members. There are 164 countries that are parties to the ICESCR, of which 160 are members of the ILO. Under the ICESCR, only four countries noted specific objections or reservations to the treaty's provisions on the right to strike at the time of becoming a party to the treaty. In so doing, each announced its objection to or clarification of how it would implement the right. Bahrain noted in its reservation that it intended to implement the right to strike, reserving its authority to prohibit strikes at "essential utilities". Norway announced that it would continue to refer labour conflicts to its State Wage Boards, and this practice it considered compatible with the right to strike in the treaty. France announced it would implement the right to strike consistent with the European Social Charter. More noteworthy was Kuwait, which reserved the right not to apply the provisions of the treaty concerning the right to strike. This raised objections from Finland, Germany, Italy, Norway and Sweden (UNTC, undated).

The list of state parties to the ICCPR and ICESCR show that the vast majority of the 153 countries that have ratified Convention No. 87 have also recognised the right to strike in other international treaties.

\section{Countries that have not ratified Convention No. 87}

The employer group has been challenging ILO Convention No. 87, claiming that it does not include the right to strike. Of the ILO's 187 member countries, 153 have ratified ILO Convention No. 87 (ILO, undated b). While this is a strong majority of ILO member states (82 per cent), the 34 
countries that have not ratified the Convention represent a significant portion of the world's population including Brazil, China, India, Malaysia, New Zealand and the United States (ILO, undated c). Nevertheless, if one takes into account other international instruments, such as the ICESCR and ICCPR, the picture that emerges is remarkably different (see Table 1).

Table 1. ILO member countries that have not ratified Convention No. 87

\begin{tabular}{|c|c|c|c|c|}
\hline \multirow[t]{2}{*}{ Country } & \multicolumn{2}{|c|}{ ICCPR Status } & \multicolumn{2}{|c|}{ ICESCR Status } \\
\hline & Action & Date & Action & Date \\
\hline 1. Afghanistan & Accession & 24 Jan 1983 & Accession & 24 Jan 1983 \\
\hline 2. Bahrain & Accession & 20 Sep 2006 & Accession & 27 Sep 2007 \\
\hline 3. Brazil & Accession & 24 Jan 1992 & Accession & 24 Jan 1992 \\
\hline 4. Brunei Darussalam & --- & --- & --- & --- \\
\hline 5. China & Signed & 5 Oct 1998 & Ratified & 27 Mar 2001 \\
\hline 6. Cook Islands & --- & --- & --- & --- \\
\hline 7. Guinea-Bissau & Ratified & 1 Nov 2010 & Accession & 2 Jul 1992 \\
\hline 8. India & Accession & 10 Apr 1979 & Accession & 10 Apr 1979 \\
\hline 9. Iran & Ratified & 24 Jun 1975 & Ratified & 24 Jun 1975 \\
\hline 10. Iraq & Ratified & 25 Jan 1971 & Ratified & 25 Jan 1971 \\
\hline 11. Jordan & Ratified & 28 May 1975 & Ratified & 28 May 1975 \\
\hline 12. Kenya & Accession & 1 May 1972 & Accession & 1 May 1972 \\
\hline 13. Laos & Ratified & 25 Sep 2009 & Ratified & 13 Feb 2007 \\
\hline 14. Lebanon & Accession & 3 Nov 1972 & Accession & 3 Nov 1972 \\
\hline 15. Malaysia & --- & --- & --- & --- \\
\hline 16. Marshall Islands & --- & --- & --- & --- \\
\hline 17. Morocco & Ratified & 3 May 1979 & Ratified & 3 May 1979 \\
\hline 18. Nepal & Accession & 14 May 1991 & Accession & 14 May 1991 \\
\hline 19. New Zealand & Ratified & 28 Dec 1978 & Ratified & 28 Dec 1978 \\
\hline 20. Oman & --- & --- & --- & --- \\
\hline 21. Palau & Signed & 20 Sep 2011 & Signed & 20 Sep 2011 \\
\hline 22. Qatar & --- & --- & --- & --- \\
\hline 23. Rep. of Korea & Accession & 10 Apr 1990 & Accession & 10 Apr 1990 \\
\hline 24. Saudi Arabia & --- & --- & --- & --- \\
\hline 25. Singapore & --- & --- & --- & --- \\
\hline 26. South Sudan & --- & --- & --- & --- \\
\hline 27. Sudan & Accession & 18 Mar 1986 & Accession & 18 Mar 1986 \\
\hline 28. Thailand & Accession & 29 Oct 1996 & Accession & 5 Sep 1999 \\
\hline 29. Tonga & --- & --- & --- & --- \\
\hline 30. Tuvalu & --- & --- & --- & --- \\
\hline 31. United Arab Emirates & --- & --- & --- & --- \\
\hline 32. United States & Ratified & 8 Jun 1992 & Signed & 5 Oct 1977 \\
\hline 33. Uzbekistan* & Accession & 28 Sep 1995 & Accession & 28 Sep 1995 \\
\hline 34. Vietnam & Accession & 24 Sep 1982 & Accession & 24 Sep 1982 \\
\hline
\end{tabular}

Note: Ratified and acceded refer to two different means by which countries may adopt a treaty. Ratified signifies that the country signed and subsequently formally ratified the treaty. Acceded means that the country formally adopted the treaty without having first signed it. There is no appreciable difference between ratifying and acceding to the treaty for purposes of obligations under the treaty. Signed means the country signed the treaty without taking further action to formally adopt the treaty.

*Uzbekistan ratified Convention No. 87 on 12 December 2016 but it will not come into force until 12 December 2017. Sources: ILO (Undated b); UN OHCHR (Undated b). 
Although thirty-four ILO member countries have not ratified Convention No. 87, nineteen of them have nevertheless ratified the ICESCR which explicitly recognises the right to strike, as well as the ICCPR. Among the largest countries, in terms of population, each is a party to at least one of the treaties that recognises the right to strike. For example, the United States ratified the ICCPR and also signed the ICESCR. Similarly, China ratified the ICESCR and signed the ICCPR. Signing a treaty rather than ratifying it entails a lower-level of obligation; nevertheless, countries that sign a treaty and do not subsequently ratify it must "refrain from acts which would defeat the object and purpose of the treaty" (UN, 1969: art 18). Clearly, the right to strike has been recognised in treaties adopted by many countries, including by the largest and most powerful ones, such as the United States and China.

Of the 187 countries that are members of the ILO, there are only thirteen countries that have neither ratified ILO Convention No. 87, nor ratified either the ICESCR or ICCPR. These countries are: Brunei Darussalam, Cook Islands, Malaysia, Marshall Islands, Oman, Palau, Qatar, Saudi Arabia, Singapore, South Sudan, Tonga, Tuvalu and United Arab Emirates. As such, recognition of the right to strike is almost universal.

\section{Countries that have ratified ILO Convention No. 87}

There are 154 ILO member states that have ratified ILO Convention No. 87. Among these there is evidence of broad commitment to recognising the right to strike beyond ILO Convention No 87. In fact, 139 of these member states (90.8 per cent) have ratified the ICESCR and ICCPR in addition to ILO Convention No. 87. There are only four countries that have ratified ILO Convention No. 87 without also having ratified, acceded to or signed either the ICESCR or ICCPR. These countries are: Antigua and Barbuda, Fiji, Kiribati, and Saint Kitts and Nevis. In summary, overwhelmingly, countries that have ratified ILO Convention No. 87 have also recognised the right to strike in other international human rights treaties.

In addition to the sheer number of countries that have recognised the right to strike in international human rights treaties as well as in ILO Convention No. 87, it is also important to note that a significant number of countries have recognised the right to strike since the inception of the employer group's campaign to derecognise the right to strike. The ILO continuously encourages member countries to ratify conventions or alternatively to explain their reasons for non-ratification. Remarkably, after initiation of employer objections to the right to strike in 1989, fifty-six ILO member countries ratified ILO Convention No. 87. In addition, seventy-seven ILO member countries have ratified or acceded to the ICCPR since 1990 and six ILO members have signed on to the ICCPR. With respect to the ICESCR, seventy ILO member countries have become parties to the treaty since 1 January 1990, and five ILO member countries have signed on to the ICESCR.

Clearly a country's signature or formal ratification of a treaty or ILO Convention does not signal compliance with and fulfilment of treaty duties and obligations. China's constitutional protection of the right to strike was removed in 1982 and strikes are not legally protected despite the fact that China became a party to the ICESCR in 2001 (Ewing, 2013; Chang and Cook, 2015: 445). Nevertheless, because China is a party to the ICESCR as well as to the ILO's 1998 Declaration on Fundamental Principles and Rights at Work, the ILO and CESCR opinions about the content of the right to strike matter in an authoritative way (Ewing, 2013). Similarly, the United States, although a party to the ICCPR since 1977, has no constitutional protection of the right to strike, and federal and 
state public employee rights to strike are severely limited. Japan has ratified ILO Convention No. 87 as well as the ICCPR and ICESCR, and has a constitutionally protected right to strike, although that right has been severely restricted by legislation and court decisions (Ishida, 2015: 312). In 2001 the CESCR issued a Concluding Observation critical of Japan's treatment of the right to strike with respect to public employees (CESCR, 2001b: -21). Japan responded by voicing its non-recognition of the ILO Committee of Expert opinions concerning the right to strike under Convention No. 87 (Japan Follow-up, 2002: \5(1)).

The CESCR has persisted in interpreting the right to strike under the ICESCR in ways that are largely congruent with the ILO. At times the CESCR has explicitly referenced the ILO Committee of Experts - for example in Poland, Malta, Korea and Jamaica (CESCR, 2002a, 2004a, 2009a, 2013), as well as the Committee on Freedom of Association in Cambodia (CESCR, 2009b). At other times, the CESCR references the ILO or ILO Conventions alone without regard to specific ILO opinions about them as, for example, in Australia, Benin, Azerbaijan, India and Montenegro (CESCR, 2000, 2002b, 2004b, 2008, 2014). Critically, the CESCR has been upholding the integrity of the content and meaning of the right to strike in its Concluding Observations of countries from all regions of the world.

\section{Conclusion}

Given the evidence, it would be disingenuous for ILO member countries that are parties to international human rights treaties recognising the right to strike to claim at the ILO that no such right exists. Indeed, government members of the ILO jointly affirmed their recognition of the right to strike at the February 2015 meeting (ILO, 2015b, 2015c). The United States also noted its recognition of the right to strike under ILO Convention No. 87 (ILO, 2015c: \16). Employers as constituents at the ILO are not parties to the ICCPR or ICESCR, and so it is not surprising that they would campaign based on their interests in undermining and narrowing union rights. Many national governments, as employers themselves, may share those anti-union interests with private-sector employers. Nevertheless, the right to strike is solidly enshrined in international human rights treaties as well as in ILO Convention No. 87, and state parties to the treaties have a duty to respect, protect and fulfil their obligations.

Although the most recent controversy has passed at the ILO, at least for the moment, the human rights and ILO foundations for the right to strike have yet to be fully enmeshed to strengthen recognition of the right to strike. Coherence between the ILO and human rights treaties systems helps ensure that the controversy does not erode the right to strike or the ILO as a global governance institution. Notably, the government group at the ILO recognised that the right to strike is encompassed within the ILO's Fundamental Principles and Rights at Work, which is a significant step forward (IndustriALL, 2015: 1; ILO, 2015b: 2, 2015c). More importantly, examination of the recent meeting documents indicates that agreement was reached in a manner that at least began to recognise the right to strike in international law apart from ILO standards (ILO, 2015c: $\mathbb{\uparrow 1 1 , ~ 1 5 , ~ 2 5 ) . ~}$ Three different government representatives speaking on behalf of Latin American and Caribbean countries, the European Union and Nordic countries explicitly noted that the right to strike is enshrined in other international instruments such as the International Covenant on Economic, Social and Cultural Rights (ILO 2015c: $\$ 11,13,15)$. The government representative speaking on behalf of the Nordic countries also noted the overlap between ratification of the ICESCR and ILO 
Convention No. 87 (ILO, 2015c: \15).

It is significant that government representatives of the European Union, Latin America, the Caribbean and Nordic countries embedded their support of the right to strike at the ILO with other existing international human rights treaty obligations such as the ICESCR. Their acknowledgement creates the potential to unite the ILO and human rights systems in one coherent framework affirming the right to strike. With support and encouragement from the CESCR and HRC, that coherence can take on a greater and more permanent influence. Hopefully, the CESCR will soon issue a General Comment on union rights under article 8 affirming the existence of the right to strike and the ILO's competence to provide useful guidance on its legitimate exercise. Human rights treaties and the UN Committees authorised to monitor their implementation have much to contribute to bolstering the legitimacy of the right to strike.

\section{REFERENCES}

Bellace, J. (2014a) The ILO and the Right to Strike. International Labour Review, 153(1): 29-70.

Bellace, J. (2014b) Human Rights at Work: The Need for Definitional Coherence in the Global Governance System. International Journal of Comparative Labour Law and Industrial Relations, 30(2): 175-198.

Chang, K. and F.L. Cooke (2015) Legislating the Right to Strike in China: Historical Development and Prospects. Journal of Industrial Relations, 57(3): 440-455.

Committee on Economic, Social and Cultural Rights (CESCR) (2000) Concluding Observations of the Committee on Economic, Social and Cultural Rights Australia: Consideration of Reports Submitted by State Parties Under Articles 16 and 17 of the Covenant E/C.12/1/Add.50. Available online at http://uhri.ohchr.org/Document/File/e013fb62-0f69-4e58-8df5-675523a63cb6/20b8cb60-4023-4cf19dc0-7d08fcee2628 [accessed 30 June 2016].

Committee on Economic, Social and Cultural Rights (CESCR) (2001a) Concluding Observations of the Committee on Economic, Social and Cultural Rights Germany: Consideration of Reports Submitted by State Parties Under Articles 16 and 17 of the Covenant, E/C.12/1/Add.68. Available online at http://uhri.ohchr.org/Document/File/210f822b-7d3b-4f19-9a1e-ebc06560c813/dc9e3fff-3489-4c01a0e7-a2397909d056 [accessed 28 June 2016].

Committee on Economic, Social and Cultural Rights (CESCR) (2001b) Concluding Observations of the Committee on Economic, Social and Cultural Rights Japan: Consideration of Reports Submitted by State Parties Under Articles 16 and 17 of the Covenant, E/C.12/1/Add.68. Available online at http://tbinternet.ohchr.org/_layouts/treatybodyexternal/Download .aspx?symbolno $=\mathrm{E} \% 2 \mathrm{fC} .12 \% 2 \mathrm{f} 2002 \% 2 \mathrm{f} 12 \&$ Lang $=$ en [accessed 28 June 2016].

Committee on Economic, Social and Cultural Rights (CESCR) (2002a) Concluding Observations of the Committee on Economic, Social and Cultural Rights Poland: Consideration of Reports Submitted by State Parties Under Articles 16 and 17 of the Covenant, E/C.12/1/Add.82. Available online at http://uhri.ohchr.org/Document/File/053b9a6e-074e-416d-981d-fe13e5b97543/b8d8da33-5576-4438891 a-6c9b3a2841ea [accessed 30 June 2016].

Committee on Economic, Social and Cultural Rights (CESCR) (2002b) Concluding Observations of the Committee on Economic, Social and Cultural Rights Benin: Consideration of Reports Submitted by State Parties Under Articles 16 and 17 of the Covenant, E/C.12/1/Add.78. Available online at http://uhri.ohchr.org/Document/File/e379b9cc-8a66-420f-8dfa-8f8dee705792/16d6bf5f-a0d9-4c5d9713-d8d82dd76666 [accessed 30 June 2016].

Committee on Economic, Social and Cultural Rights (CESCR) (2004a) Concluding Observations of the 
Committee on Economic, Social and Cultural Rights Malta: Consideration of Reports Submitted by State Parties Under Articles 16 and 17 of the Covenant, E/C.12/1.Add.101. Available online at http://uhri.ohchr.org/Document/File/bf909a72-facd-42ff-8a98-d330d5f08bb6/ed0cf89a-fbfe-4425-

9469-cf18f7a58936 [accessed 30 June 2016].

Committee on Economic, Social and Cultural Rights (CESCR) (2004b) Concluding Observations of the Committee on Economic, Social and Cultural Rights Azerbaijan: Consideration of Reports Submitted by State Parties Under Articles 16 and 17 of the Covenant, E/C.12/1/Add.104. Available online at http://uhri.ohchr.org/Document/File/916f8b8e-7d53-4452-bc50-a14868f31be4/50aced1e-5ea9-4f58ad39-4a59751cd2e7 [accessed 30 June 2016].

Committee on Economic, Social and Cultural Rights (CESCR) (2006) General Comment No. 18: The Right to Work (Art. 6 of the Covenant), E/C.12/GC/18. Available online at: http://tbinternet.ohchr.org/_layouts/treatybodyexternal/Download.aspx?symbolno=E $\% 2 \mathrm{fC} .12 \% 2 \mathrm{fGC}$ $\% 2 \mathrm{f} 18 \&$ Lang=en [accessed 28 June 2016].

Committee on Economic, Social and Cultural Rights (CESCR) (2008) Concluding Observations of the Committee on Economic, Social and Cultural Rights India: Consideration of Reports Submitted by State Parties Under Articles 16 and 17 of the Covenant, E/C.12/IND/CO/5. Available online at http://uhri.ohchr.org/Document/File/b8349902-6690-49d7-af6a-49029a9d9976/f6bf6bb6-e393-4be595ce-fd14d16bd49c [accessed 30 June 2016].

Committee on Economic, Social and Cultural Rights (CESCR) (2009a) Concluding Observations of the Committee on Economic, Social and Cultural Rights Republic of Korea: Consideration of Reports Submitted by State Parties Under Articles 16 and 17 of the Covenant, E/C.12/KOR/CO/3. Available online at http://uhri.ohchr.org/Document/File/c324005a-1e02-4a1b-810f-cdceb58cfaa4/def81661bf80-4ad7-bcba-23d20b61ebcf [accessed 30 June 2016].

Committee on Economic, Social and Cultural Rights (CESCR) (2009b) Concluding Observations of the Committee on Economic, Social and Cultural Rights Cambodia: Consideration of Reports Submitted by State Parties Under Articles 16 and 17 of the Covenant, E/C.12/KHM/CO/3. Available online at http://uhri.ohchr.org/Document/File/ad420aaf-423e-4480-b4a4-ef8ce3ade0b2/33f47d14-9066-4d4c8a87-866632b207e2 [accessed 30 June 2016].

Committee on Economic, Social and Cultural Rights (CESCR) (2013) Concluding Observations of the Committee on Economic, Social and Cultural Rights Jamaica: Consideration of Reports Submitted by State Parties Under Articles 16 and 17 of the Covenant, E/C.12/JAM/CO/3-4. Available online at http://uhri.ohchr.org/Document/File/e766ac04-9b37-4043-860e-018aec3f90f8/5eacffa1-9f98-44d58c18-b3d8a90f2463 [accessed 30 June 2016].

Committee on Economic, Social and Cultural Rights (CESCR) (2014) Concluding Observations of the Committee on Economic, Social and Cultural Rights Montenegro: Consideration of Reports Submitted by State Parties Under Articles 16 and 17 of the Covenant, E/C.12/MNE/CO/1. Available online at http://uhri.ohchr.org/Document/File/af49ffef-9ced-4fe2-add7-4245336c0741/4ef0e5eb-7b11-47479d7d-0c8967cc6926 [accessed 30 June 2016].

Craven, M. (1995) The International Covenant on Economic, Social and Cultural Rights: A Perspective on its Development. Oxford: Clarendon Press.

Ewing, K.D. (2013) Myth and Reality of the Right to Strike as a "Fundamental Labour Right". International Journal of Comparative Labour Law and Industrial Relations, 29(2): 145-166.

Fudge, J. (2015) Constitutionalizing Labour Rights in Canada and Europe: Freedom of Association, Collective Bargaining and Strikes. Current Legal Problems, 68: 267-305.

Hofmann, C. (2014) (The Right to) Strike and the International Labour Organization: Is the System for Monitoring Labour and Social Standards in Trouble? Friedrich Ebert Stiftung. Available online at http://library.fes.de/pdf-files/iez/10775.pdf [accessed 25 February 2015]. 
IndustriALL (2015) Global Union Statement: Statement Following ILO Tripartite Meeting 26, February 2015. Available online at http://www.industriall-union.org/right-to-strike-upheld-at-ilo (accessed 16 January 2017).

International Labour Organisation (ILO) (Undated a) How the ILO Works. Available online at http://www.ilo.org/global/about-the-ilo/how-the-ilo-works/lang--en/index.htm [accessed 25 February 2015].

International Labour Organisation (ILO) (Undated b) NORMLEX Convention Ratifications. Available online at http://www.ilo.org/dyn/normlex/en/f?p=NORMLEXPUB:11300:0::NO:11300:P11300_ INSTRUMENT_ID:312232:NO [accessed 25 February 2015].

International Labour Organisation (ILO) (Undated c) NORMLEX Convention Non Ratifications. Available online at https://www.ilo.org/dyn/normlex/en/f?p=NORMLEXPUB:11310:0::NO:11310:P11310 _INSTRUMENT_ID:312232:NO [accessed 16 January 2017].

International Labour Organisation (ILO) (1998) Declaration on Fundamental Principles and Rights at Work. Available online at http://www.ilo.org/declaration/thedeclaration/textdeclaration /lang--en/index.htm [accessed 25 February 2015].

International Labour Organisation (ILO) (2014) Governing Body Draft Minutes, GB.322/INS/PV/DRAFT. Available online at http://www.ilo.org/wcmsp5/groups/public/---ed_norm/---elconf/ documents/ meetingdocument/wcms_341702.pdf [accessed 25 February 2015].

International Labour Organisation (ILO) (2015a) Background Document for the Tripartite Meeting on the Freedom of Association and Protection of the Right to Organise Convention, 1948 (No. 87), in relation to the right to strike and the modalities and practices of strike action at national level. Available online at http://www.ilo.org/wcmsp5/groups/public/---ed_norm/---

relconf/documents/meetingdocument/wcms_344248.pdf [accessed 25 February 2015].

International Labour Organisation (ILO) (2015b) Outcome of Meeting, Tripartite Meeting on Freedom of Association and Protection of the Right to Organise Convention, 1948 No. 87, in relation to the right to strike and the modalities and practices of strike action at national level Appendix. 23-25 February 2015. Available online at http://www.ilo.org/wcmsp5/ groups/public/---ed_norm/---elconf/ documents/meetingdocument/wcms_346764.pdf [accessed 4 May 2015].

International Labour Organisation (ILO) (2015c) Final Report of the Meeting, Tripartite Meeting on Freedom of Association and Protection of the Right to Organise Convention, 1948 (no. 87), in relation to the right to strike and modalities and practices of strike action at national level. Available online at http://www.ilo.org/wcmsp5/groups/public/---ed_norm/---relconf/documents/meetingdocument/ wcms_349069.pdf [accessed 4 May 2015].

International Organization of Employers (2013) IOE Guidance Document Convention 87. Available online at http://payamekarfarmayan.com/IMG/pdf/_-_-_78.pdf [accessed 25 February 2015].

International Organization of Employers (IOE) (2014) IOE Report of the 322nd Session of the ILO Governing Body 30 October to 13 November 2014. Available online at http://media.rspp.ru /document/1/6/5/6509e7b939bba59167d56c11592f246e.pdf [accessed 25 February 2015].

International Trade Union Confederation (ITUC) (2014a) ITUC Statement on Human Rights Day, 10 December 2014. Available online at http://www.ituc-csi.org/ituc-statement-on-human-rights-day-15419 [accessed 25 February 2015].

International Trade Union Confederation (ITUC) (2014b) The Right to Strike and the ILO: The Legal Foundations. Available online at http://www.ituc-csi.org/IMG/pdf/ituc_final_brief _on_the_ right_to_strike.pdf [accessed 25 February 2015].

International Trade Union Confederation (ITUC) (2015) Resolution on CAS Dispute. Available online at http://www.ituc-csi.org/IMG/pdf/14gc_e_08_-_ilo.pdf [accessed 25 February 2015]. 
Ishida, S. (2015) The Right to Strike in Japan: A Need to Restore Its Political Function. Kings Law Journal, 26(2): 312-327.

La Hovary, C. (2013) Showdown at the ILO? A Historical Perspective on the Employers Group's 2012 Challenge to the Right to Strike. Industrial Law Journal, 42(4): 338-368.

Japan Follow-up State Reporting Action by State Party (Japan Follow-up) (2002) CESCR E/C.12/2012/12. Available online at http://www.bayefsky.com/html/japan_cescr_follow_report.php [accessed 28 June 2016].

Macklem, P. (2005) The Right to Bargain Collectively in International Law: Workers' Right, Human Right, International Right? In Labour Rights as Human Rights, edited by P. Alston. Oxford: OUP.

MacNaughton, G. and D. Frey (2011) Decent Work for All: A Holistic Human Rights Approach. American University International Law Review, 26(2): 441-483. Available online at http://digitalcommons wcl.american.edu/cgi/viewcontent.cgi?article $=1704 \&$ context $=$ auilr [accessed 25 February 2015].

Novitz, T. (2003) International and European Protection of the Right to Strike. Oxford: OUP.

Saskatchewan Federation of Labour v Saskatchewan (2015) SCC 4. Available online at https://scccsc.lexum.com/scc-csc/scc-csc/en/item/14610/index.do [accessed 27 June 2016].

Saul, B., D. Kinley and J. Mowbray (2014) The International Covenant on Economic, Social and Cultural Rights: Commentary, Cases and Materials. Oxford: OUP.

Scheinin, M. and M. Langford (2009) Evolution or Revolution? Extrapolating from the Experience of the Human Rights Committee. Nordisk. Tidsskrift For Menneskerettighter, 27(1): 97-113.

United Nations (1969) Vienna Convention on the Law of Treaties. Available online at http://www.refworld.org/docid/3ae6b3a10.html [accessed 20 February 2015].

United Nations General Assembly (1966) International Covenant on Civil and Political Rights (ICCPR). Available online at http://www.refworld.org/docid/3ae6b3aa0.html [accessed 18 February 2015].

United Nations General Assembly (1966) International Covenant on Economic, Social and Cultural Rights (ICESCR). Available online at http://www.refworld.org/docid/3ae6b36c0.html [accessed 18 February 2015].

United Nations, Human Rights Committee (HRC) (1986) J.B. et al. v. Canada, Communication No. 118/1982, U.N. Doc. Supp. No. 40 (A/41/40) at 151 . Available online at http://www1.umn.edu/humanrts/undocs/session41/118-1982.htm [accessed 1 July 2016].

United Nations, Human Rights Committee (HRC) (1999) Concluding Observations of the Human Rights Committee: Chile, 24 March 1999, CCPR/C/79/Add.104. Available online at http://hrlibrary.umn.edu/hrcommittee/chile1999.html [accessed 16 January 2017].

United Nations, Human Rights Committee (HRC) (2004) Concluding Observations of the Human Rights Committee: Lithuania, 5 April 2004, CCPR/CO/80/LTU. Available online at http://hrlibrary.umn.edu/hrcommittee/lithuania2004.html [accessed 16 January 2017].

United Nations, Human Rights Committee (HRC) (2010) Concluding Observations of the Human Rights Committee: Estonia, 4 August 2010, CCPR/C/EST/CO/3. Available online at http://www1.umn.edu/humanrts/hrcommittee/estonia2010.html [accessed 1 July 2016].

United Nations, Office of the High Commissioner of Human Rights (OHCHR) (Undated a) Committee on Economic, Social and Cultural Rights. Available online at http://www.ohchr.org/EN/HRBodies/CESCR/ Pages/CESCRIntro.aspx [accessed 27 June 2016].

United Nations, Office of the High Commissioner for Human Rights (OHCHR) (Undated b) Status of Ratifications. Available online at http://indicators.ohchr.org [accessed 17 June 2015].

United Nations Treaty Collection (UNTC) (Undated) Available online at https://treaties. 
un.org/Pages/ViewDetails.aspx?src=IND\&mtdsg_no=IV-3\&chapter=4\&clang=_en $\quad[$ accessed 16 January 2017].

Van de Heijden, P.F. (2013) International Right to Strike Under Stress. The Hague Institute for Social Justice. Available online at http://www.fnv.nl/site/nieuws/nieuwsberichten/970113/994970/ International _Right_to_Strike_Under_Stress.pdf [accessed 25 February 2015].

\section{BIOGRAPHICAL NOTE}

DIANE FREY is currently a lecturer in Labour Studies at San Francisco State University and an adjunct lecturer in negotiation at Harvard University Extension School. She was previously the Director of Labor Studies at the National Labor College. For over twenty years she was a labour organiser and representative for several unions in the United States. She received her $\mathrm{PhD}$ in Comparative Employment Relations from the London School of Economics. [Email: dianefrey@hotmail.com] 